\title{
An assessment of the changes in water chemistry and in the macroinvertebrate community produced during the creation of the new Llobregat river mouth (Barcelona, NE Spain)
}

\author{
Miguel Cañedo-Argüelles ${ }^{1, *}$ and Maria Rieradevall ${ }^{1,2}$ \\ ${ }^{1}$ Grup de Recerca Freshwater Ecology and Management (FEM), Departament d'Ecologia, Facultat de Biologia, \\ Universitat de Barcelona (UB), Diagonal 643, 08028 Barcelona, Spain. \\ ${ }^{2}$ Institut de Recerca de Biodiversitat (IRBio), Universitat de Barcelona. \\ * Corresponding author: mcanedo.fem@gmail.com
}

Received: 6/3/12 Accepted: 29/6/12

\begin{abstract}
An assessment of the changes in water chemistry and in the macroinvertebrate community produced during the creation of the new Llobregat river mouth (Barcelona, NE Spain)

In 1999, a set of coordinated projects and investments whose principal objective was to transform Barcelona into one of the main distribution points of southern Europe resulted in the relocation of the Llobregat River mouth. The mouth was relocated by draining the old river mouth and constructing a new one. The aim of this study was to characterise the physico-chemical properties and the aquatic macroinvertebrate communities of the new river mouth and to monitor the changes experienced by the estuarine environment during its creation. A sampling point was established in the river $1.8 \mathrm{~km}$ upstream from its connection with the new mouth, and two sampling points were established in the new mouth. Samples of water and macroinvertebrates were collected every two months from May 2004 to June 2005, covering the periods before (from May to September 2004) and after (from September 2004 to June 2005) the new mouth was connected to the river and the sea. During the period before its connection to the river and the sea, the new mouth was functionally similar to a lagoon, with clear waters, presence of Chara and a rich invertebrate community. After the connection was completed, seawater penetrated the river mouth and extended to the connection point with the river (approximately $3.9 \mathrm{~km}$ upstream). An increase in conductivity from 4-6 mS cm$~^{-1}$ to $24-30 \mathrm{mS} \mathrm{cm}{ }^{-1}$ caused important changes in the macroinvertebrate community of the new mouth. An initial defaunation was followed by a colonisation of the new mouth by brackish-water and marine invertebrate species. Due to its design (which allows the penetration of the sea) and the decreased discharge from the lower part of the Llobregat River, the new mouth has become an arm of the sea.
\end{abstract}

Key words: River diversion, river mouth, human impact, aquatic macroinvertebrates, chironomids.

\section{RESUMEN}

Caracterización de las propiedades físico-químicas y la comunidad de macroinvertebrados acuáticos de la nueva desembocadura del Río Llobregat (Barcelona, NE España)

En 1999 la desembocadura del Río Llobregat fue desviada como consecuencia de una acción coordinada de proyectos cuyo principal objetivo era el de transformar Barcelona en uno de los principales puntos de distribución de mercancías del sur de Europa. En el presente estudio se caracterizan las propiedades físico-químicas y la comunidad de macroinvertebrados acuáticos de la nueva desembocadura, y se monitorizan los cambios experimentados por el ecosistema durante su creación. Un punto de muestreo se situó en el Río Llobregat, $1.8 \mathrm{~km}$ aguas arriba de su conexión con la nueva desembocadura, y dos puntos de muestreo se situaron en la nueva desembocadura. Se recogieron muestras de agua y de macroinvertebrados cada dos meses desde Mayo de 2004 hasta Junio de 2005, período que incluyó el antes (desde Mayo hasta Septiembre de 2004) y el después (desde Septiembre de 2004 hasta Junio de 2005) de que la nueva desembocadura fuera conectada al río y al mar. Durante el período anterior a su conexión con el río y el mar la nueva desembocadura funcionaba como una laguna, presentando aguas claras, presencia de Chara y una comunidad de macroinvertebrados rica en especies. Después de ser conectada al río y el mar, el agua de mar penetró en la desembocadura hasta el punto de conexión con el río 
(aproximadamente unos $3.9 \mathrm{~km}$ aguas arriba). La conductividad de la desembocadura aumentó de 4-6 $\mathrm{mS}_{\mathrm{cm}}^{-1}$ a $24-30 \mathrm{mS}$ $\mathrm{cm}^{-1}$, causando importantes cambios en la comunidad de macroinvertebrados acuáticos. Se registró una pérdida de fauna inicial seguida de una colonización de fauna marina y de aguas salobres. Debido a su diseño (que permite la entrada de grandes cantidades de agua de mar) y al escaso caudal del tramo bajo del Llobregat, la nueva desembocadura se ha convertido en un brazo de mar.

Palabras clave: Desvío del río, desembocadura, impacto humano, macroinvertebrados acuáticos, quironómidos.

\section{INTRODUCTION}

Urban development is concentrated in the coastal zones of the world, and these coastal populations are growing more rapidly than the global average. Recent calculations showed that $2.69 \cdot 10^{9}$ people (44 percent of the world's population) live within the coastal zone (Crossland et al., 2005). The average human population density in coastal areas is approximately 80 persons per square kilometre, twice the global average (http://earthwatch. unep.ch/oceans/coastalthreats.php). This massive human presence along the coastline is translated into a wide variety of pressures (e.g., wastewater discharges, landscape fragmentation and habitat destruction) on coastal ecosystems. In certain areas, the growth of the population and the infrastructures is reaching a point at which there is no more available space and a reconfiguration of the natural landscape is required. The city of Barcelona and its metropolitan area (Spain) represent a clear example of this situation.

Barcelona is the second largest city in Spain (5 507813 inhabitants in 2009 in the metropolitan area, according to the Spanish Institute of Statistics: http://www.ine.es), and it is a hotspot for the trade in goods and services within Europe. The growth of the population and the development of the economy have forced the city to expand. However, the expanding city faces four physical barriers: the Collserola Mountains in the West, the Mediterranean Sea in the East, the Besòs River in the North and the Llobregat River in the South. In 1999, the Delta Plan, a largescale project costing 6750 million euros, was launched. The Delta Plan consisted of a set of coordinated projects and investments whose main objective was to transform Barcelona into "the main distribution point of southern Europe" (Catalonian Government, available at: http://www. gencat.net). The Delta Plan involved the expansion of Barcelona's port. The planned expansion would double the rate of the trade in goods by doubling the surface area of the port. This space requirement resulted in the relocation of the Llobregat River's estuary by draining the old river mouth and constructing a new one.

Aquatic macroinvertebrates were chosen as the focus of the study because this group of organisms is very rich in species (Barnes, 1995; Tachet et al., 2000) that can occur over a wide range of environmental conditions and can show rapid responses to any change in the environment (e.g., Merritt \& Cummins, 1996; Batzer et al., 1999; Bilton et al., 2001; Basset et al., 2006; Jackson \& Füreder, 2006). Aquatic macroinvertebrates have been widely used as indicators of water quality and ecosystem health status (Bonada et al., 2006), and they are one of the key elements of the European Water Framework Directive .(European Commission, 2000), intended to achieve a good water quality in all European water bodies. The objective of this study was to characterise the physico-chemical properties and the aquatic macroinvertebrate communities of the new river mouth and to monitor the changes experienced during its creation. The study sought to report the environmental effects of a group of large engineering projects. Such effects are rarely assessed, and they remain unpublished in most cases. 


\section{METHODS}

\section{Study site}

The Llobregat River is the principal river in Barcelona (NE Spain). It forms a delta of $97 \mathrm{~km}^{2}$ upon reaching the Mediterranean Sea. The excavation of a new river mouth began in 2001 and was completed in May 2004. The river mouth remained closed (to the river in its upper part and to the sea at its outlet) for several months. During this period, it was fed exclusively by groundwater. The inlet and outlet of the river mouth were opened in September 2004. The new river mouth is $3.9 \mathrm{~km}$ long and $250 \mathrm{~m}$ wide, with a mean depth of $2 \mathrm{~m}$. Because the depth of the river was approximately $0.4 \mathrm{~m}$, an extensive slope was formed at the junction of the river and the new mouth. The banks of the new mouth were constructed of granite blocks. Aquatic and terrestrial vegetation were completely absent. The right levee was designed to allow overflow by the river during flood episodes, based on a return period of 25 years (Sánchez-Juny \& Dolz, 2004). The flood waters would inundate a wetland area that includes Special Protection Zones for Birds
(Community Directive 79/409/EEC) and areas protected by the Catalonian Government.

\section{Sampling design}

A sampling point (station 3) was established in the river, $1.8 \mathrm{~km}$ upstream from its connection with the new mouth. Two additional sampling points were located in the new mouth, one near the sea (station 1) and the other (station 2) $3 \mathrm{~km}$ landwards from the coastline (Fig. 1). Initially, a sampling point was established a few hundred metres above the connection, but constant and unpredictable disturbances linked to the engineering projects invalidated the preliminary results obtained from this site and later made access to the site impossible. Previous surveys from the 80s (Prat et al., 1983) and from 2001 (Alonso et al., 2001) reported that invertebrates were absent from the old river mouth. The lower part of the Llobregat River was severely polluted by urban and industrial wastes coming from the catchment (Millet \& Prat, 1984; Prat \& Rieradevall, 2006) and registered anoxic conditions that prevented the establishment of invertebrate communities. These previous conditions cannot

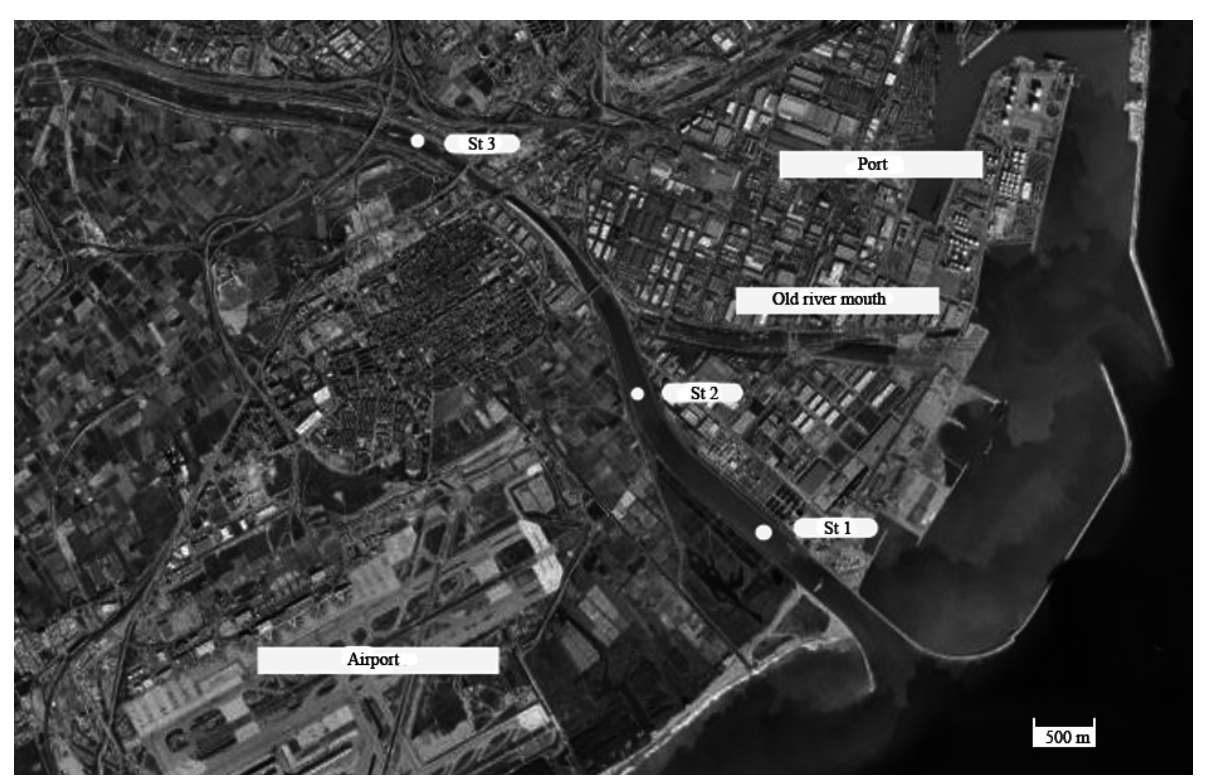

Figure 1. Study site. White dots mark the sampling stations in the new mouth (stations 1 and 2) and the river (station 3). Satellite image source: Institut Cartogràfic de Catalunya. Zona de estudio. Los puntos blancos marcan las localidades de muestreo en la nueva desembocadura (localidades 1 y 2) y en el río (localidad 3). Fuente de la imagen de satélite: Institut Cartogràfic de Catalunya. 
be considered to represent a suitable goal in terms of environmental planning. After the recent initiation of wastewater control and the construction of a new large wastewater treatment plant (WTP) in the area, we expect an improvement in the water quality in the lower Llobregat River (similar to the current ecological status of nearby upstream stretches). Therefore, the upstream sampling site served to exemplify a relevant set of potential ecological conditions because of its communities of pollution- and salinitytolerant invertebrate species (e.g., Chironomus riparius, Cricotopus sylvestris; see Cañedo-Argüelles \& Rieradevall 2009 for pollution and salinity tolerances) that could colonise the new mouth. Water and macroinvertebrate samples were collected every two months from May 2004 to June 2005, covering the periods before (from May to September 2004) and after (from September 2004 to June 2005) the new mouth was connected to the river and the sea.

\section{Physico-chemical characterisation}

Water conductivity, $\mathrm{pH}$, temperature and dissolved oxygen were measured in situ using a multi-parametric sensor (WTW, multiparameter model 197i). Transparency (Secchi disk) was also recorded in the field. One litre of surface water was collected and kept at a cold temperature for laboratory analyses of dissolved inorganic nutrients $\left(\mathrm{NH}_{4}^{+}, \mathrm{NO}_{3}^{-}, \mathrm{NO}_{2}^{-}, \mathrm{PO}_{4}^{3-}\right.$, TP and $\mathrm{Si}^{2+}$ ), total organic carbon (TOC), suspended solids (SSP) and major ions $\left(\mathrm{SO}_{4}^{2-}, \mathrm{Cl}^{-}, \mathrm{Ca}^{2+}\right.$, $\mathrm{Mg}^{2+}, \mathrm{Na}^{+}$, and $\mathrm{K}^{+}$), following standard methods (Greenberg et al., 1999).

\section{Collection and identification of aquatic macroinvertebrates}

Multihabitat samples were collected by kicking at the substrate in all the available habitats for one minute and collecting the suspended material with a $250 \mu \mathrm{m}$ mesh size dip net. To complement these samples, sediment was collected at the deepest points of stations 1 and 2 (maximum depth 2 meters) with a Van Veen grab sampler $\left(\right.$ area $\left.=298.8 \mathrm{~cm}^{-2}\right)$. Three replicates of each sample type were collected at each sampling station. The samples were fixed in $4 \%$ formaldehyde. In the laboratory, the samples were rinsed through a $250 \mu \mathrm{m}$ mesh size net. The macroinvertebrates were removed and preserved in $90 \%$ ethanol for identification. Most taxa were identified to species level. Oligochaetes and certain Diptera were identified to family level, and certain chironomids were identified to genus level.

\section{Data analysis}

Conductivity and oxygen profiles were constructed with SURFER 8.0 software (Golden Software). The macroinvertebrate community data were analysed using the Principal Response Curve (PRC) method (van den Brink \& Ter Braak, 1999), which is designed to evaluate the temporal responses of communities to disturbance. The PRC method is a form of redundancy analysis and generates series of curves that represent the extent and direction of differences between the impacted communities and the controls. It is a useful method for visualising the trajectories of community responses to disturbance along time. The PRC analysis was performed in CANOCO version 4.5 (ter Braak \& Smilauer, 2002) with the average relative abundances of macroinvertebrates in the multihabitat samples from the three stations on each sampling date. The resulting PRC diagram displays the first principal component of the redundancy analysis over time and can be interpreted as the deviation of the impacted community (the new mouth) from the control (the upstream section of the Llobregat River). Two different groups of samples were then defined for the impacted communities: before (from May to September 2004) and after (from September 2004 to June 2005) the new mouth was connected to the river and the sea. After the groups were defined, an IndVal analysis was performed with PCORD 4.20 (McCune \& Mefford, 1999) to identify the taxa significantly associated with each group. Indicator values analysis (IndVal) is based on the comparison of relative abundances and relative frequencies of taxa in the a priori defined site groups (Dufrêne \& Legendre, 1997). Each taxon 
is associated with an indicator value (IV value) that varies between 0 and 100 and a $\rho$-value obtained by Monte Carlo permutations (9999 runs). The $\rho$-value specifies the taxon's probability of assignment at random to the most probable of the defined site groups. Only taxa with a $\rho$-value of 0.05 were considered key taxa.

\section{RESULTS}

\section{Physico-chemical characterisation}

A smooth physico-chemical gradient could be observed in the new mouth throughout the study period. Upstream, conductivity decreased, whereas total phosphorus and suspended solids increased. The oxidized forms of nitrogen were dominant downstream, whereas the reduced forms were dominant upstream (Table 1). Before the connection of the new mouth to the river and to the sea, the physico-chemical characteristics of the new mouth resembled those of the river (Table 1); although conductivity was higher than at station 3, and nutrient concentrations were lower. After the connection was made, the new mouth showed a significant increase in water conductivity and in the concentrations of nutrients, suspended solids and major ions (Table 1). The increase in water conductivity was slightly higher at station 1 (closer to the sea) than at station 2 , and no vertical stratification of salinity was recorded during the study period (Fig. 2). The connection of the mouth to the river and the sea also affected the dissolved oxygen concentrations, which decreased from saturation $(100 \%)$ to $40-60 \%$ at stations 1 and 2 , increasing again at the end of the study at station 1 , where values greater than $300 \%$ were recorded in June 2005 (Fig. 3).

Table 1. Physico-chemical characterization of the river (station 3) and the new mouth (stations 1 and 2) before and after its opening to the river and the sea. Only those variables which experienced a significant change (tested by ANOVA) after the connection are shown. In order to avoid redundant information soluble reactive phosphorous is not shown as being significantly correlated with total phosphorous (TP), and $\mathrm{Ca}^{2+}, \mathrm{Mg}^{2+}$ and $\mathrm{Na}^{+}$are not shown as being significantly correlated to $\mathrm{K}^{+}$and $\mathrm{Cl}^{-}$. Características físicoquímicas del río (localidad 3) y de la nueva desembocadura (localidades 1 y 2) antes y después de la conexión de esta última con el río y con el mar. Solo se muestran aquellas variables que registraron cambios significativos (analizados mediante ANOVA) después de la conexión. Para evitar redundancias el fósforo reactivo soluble (significativamente correlacionado con el fósforo total) y el Ca ${ }^{2+}$, $\mathrm{Mg}^{2+}$ y $\mathrm{Na}^{+}$(significativamente correlacionados con el $\mathrm{K}^{+}$y el $\mathrm{Cl}^{-}$) no se muestran en la tabla.

\begin{tabular}{|c|c|c|c|c|c|}
\hline & $\begin{array}{l}\text { Conductivity } \\
\mathrm{mS} \mathrm{cm}^{-1}\end{array}$ & $\begin{array}{l}\mathrm{NO}_{2}^{-} \\
\mathrm{mg} \mathrm{l}^{-1}\end{array}$ & $\begin{array}{l}\mathrm{NO}_{3}^{-} \\
\mathrm{mg} \mathrm{l}^{-1}\end{array}$ & $\begin{array}{c}\mathrm{NH}_{4}^{+} \\
\mathrm{mg} \mathrm{l}^{-1}\end{array}$ & $\begin{array}{c}\mathrm{TP} \\
\mathrm{mg} \mathrm{l}^{-1}\end{array}$ \\
\hline \multicolumn{6}{|l|}{ St 1} \\
\hline Before connection & $6.2( \pm 0.6)$ & $0.02( \pm 0)$ & $0.60( \pm 0.14)$ & $0.12( \pm 0.03)$ & $0.04( \pm 0)$ \\
\hline After connection & $30.2( \pm 4.9)$ & $0.53( \pm 0.12)$ & $6.03( \pm 2.24)$ & $7.19( \pm 1.95)$ & $0.37( \pm 0.10)$ \\
\hline \multicolumn{6}{|l|}{ St 2} \\
\hline Before connection & $4.7( \pm 0.2)$ & $0.02( \pm 0)$ & $0.60( \pm 0.14)$ & $0.11( \pm 0.03)$ & $0.04( \pm 0)$ \\
\hline After connection & $24.4( \pm 5.1)$ & $0.56( \pm 0.11)$ & $5.50( \pm 2.33)$ & $9.58( \pm 2.31)$ & $0.52( \pm 0.10)$ \\
\hline \multicolumn{6}{|l|}{ St 3} \\
\hline \multirow[t]{3}{*}{ Annual mean } & $1.7( \pm 0.2)$ & $0.87( \pm 0.17)$ & $7.58( \pm 1.19)$ & $12.14( \pm 6.43)$ & $0.78( \pm 0.30)$ \\
\hline & SSP & $\mathrm{Cl}^{-}$ & $\mathrm{SO}_{4}^{2-}$ & $\mathrm{K}^{+}$ & $\mathrm{Si}^{2+}$ \\
\hline & $\mathrm{mg}^{-1}$ & $\mathrm{~g} \mathrm{l}^{-1}$ & $\mathrm{~g} \mathrm{l}^{-1}$ & $\mathrm{mg} \mathrm{l}^{-1}$ & $\mathrm{mg} \mathrm{l}^{-1}$ \\
\hline \multicolumn{6}{|l|}{ St 1} \\
\hline Before connection & $0.03( \pm 0)$ & $0.73( \pm 0.53)$ & $0.40( \pm 0.50)$ & $24.5( \pm 2.2)$ & $0.41( \pm 0.15)$ \\
\hline After connection & $0.20( \pm 0.03)$ & $8.33( \pm 2.47)$ & $2.22( \pm 0.67)$ & $145.3( \pm 19.1)$ & $0.73( \pm 0.11)$ \\
\hline \multicolumn{6}{|l|}{ St 2} \\
\hline Before connection & $0.06( \pm 0)$ & $1.30( \pm 0.38)$ & $0.53( \pm 0.07)$ & $32.7( \pm 5.5)$ & $0.44( \pm 0.19)$ \\
\hline After connection & $0.34( \pm 0.09)$ & $6.44( \pm 1.49)$ & $1.90( \pm 0.54)$ & $165.9( \pm 31.8)$ & $0.86( \pm 0.05)$ \\
\hline \multicolumn{6}{|l|}{ St 3} \\
\hline Anпиal mean & $0.11( \pm 0.02)$ & $0.40( \pm 0.99)$ & $0.23( \pm 0.03)$ & $32.4( \pm 3.4)$ & $1.36( \pm 0.25)$ \\
\hline
\end{tabular}




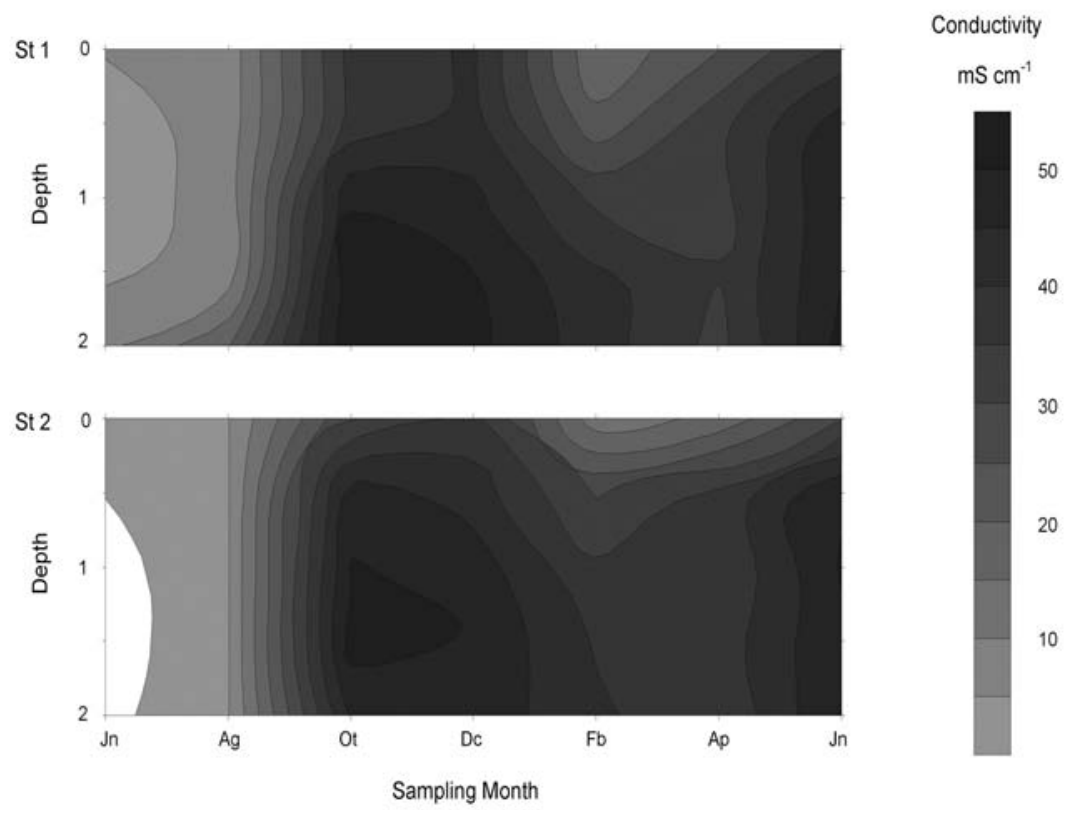

Figure 2. Depth conductivity profile (measured in $\mathrm{mS} \mathrm{cm}^{-1}$ ) for the new river mouth (stations 1 and 2) along the study period (June 2004-June 2005). Perfil vertical de conductividad (medida en $\mathrm{mS} \mathrm{cm}^{-1}$ ) de la nueva desembocadura localidades 1 y 2) durante el período de estudio (Junio 2004-Junio 2005).

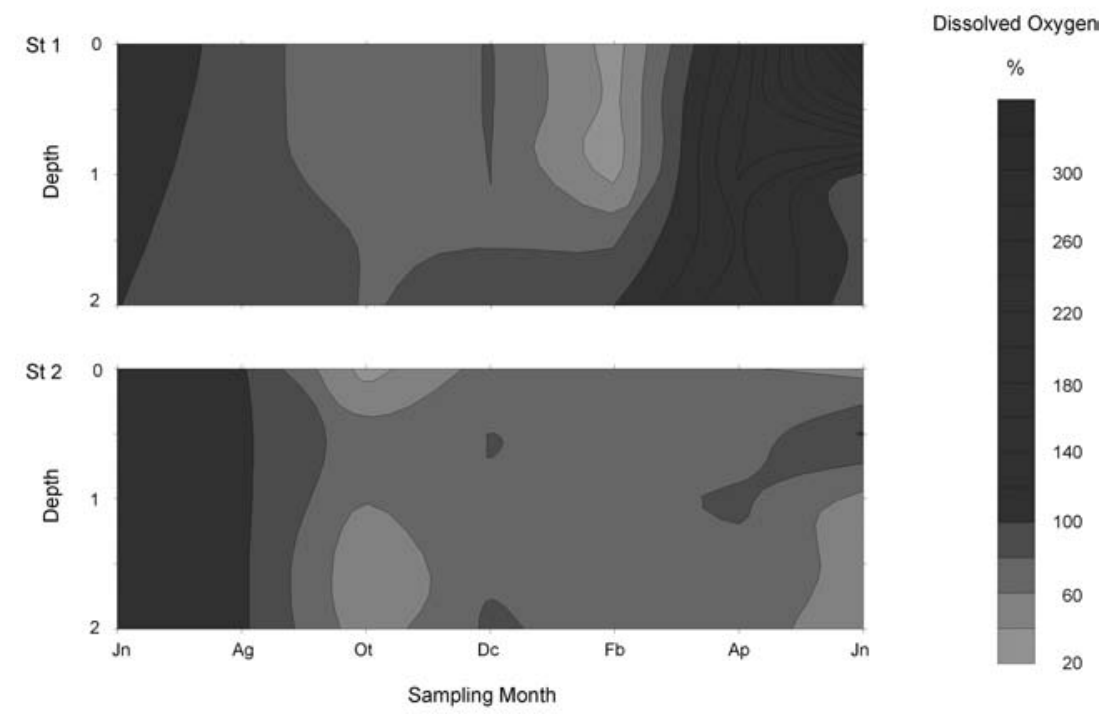

Figure 3. Depth oxygen profile (measured in \%) for the new river mouth (stations 1 and 2) along the study period (June 2004-June 2005). Perfil vertical de oxígeno (medido en \%) de la nueva desembocadura (localidades 1 y 2) durante el período de estudio (Junio 2004-Junio 2005).

\section{Aquatic macroinvertebrates}

A total of 39 macroinvertebrate taxa were recorded, of which $11(28 \%)$ were shared between the new mouth (stations 1 and 2) and the upstream river channel (station 3 ) before their connection, whereas only $2(5 \%)$ were shared after the connection. The connection of the new mouth with the river and the sea produced a drastic decrease in the densities of aquatic macroinvertebrates (from $1005 \pm 393$ to $101 \pm 39$ individuals per square metre in the sediment samples). According to the PRC analysis, the commun- 
ities of the mouth resembled those of the river before the connection, whereas they became increasingly different afterwards (Fig. 4). The difference between the mouth and the riverine communities was highest at station 1 , which was closest to the sea. Before the connection, both the littoral and the sediment communities of the new mouth were characterised by a dominance of chironomids $(84 \%$ and $73 \%$ of total abundance, respectively) and other insects (9 and $21 \%$ of total abundance, respectively) (Fig. 5). After the connection, oligochaetes (primarily Enchytraeidae) dominated the sediment (89\%

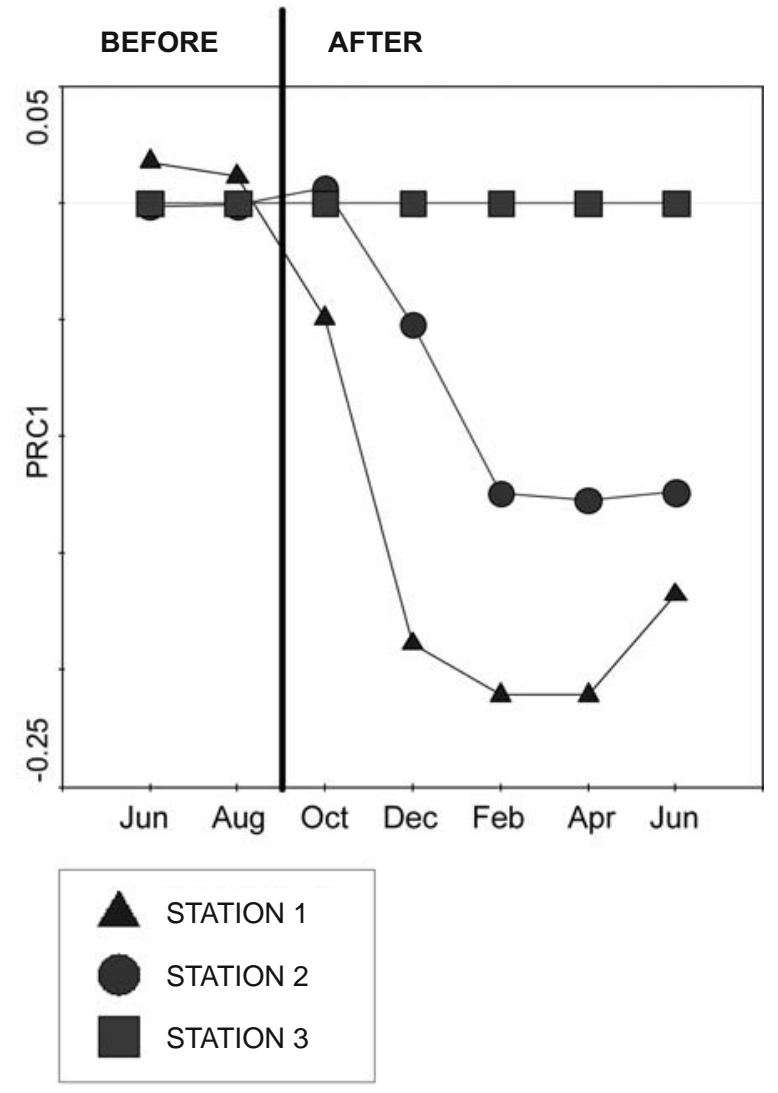

Figure 4. Principal response curve (PRC) showing the trajectories of the invertebrate community along time, which can be interpreted as the deviation in the new mouth community (stations 1 and 2) from the upstream (station 3). Curvas de respuesta principales (PRC) mostrando las trayectorias de las comunidades de invertebrados a lo largo del tiempo. Las trayectorias pueden interpretarse como la desviación de las comunidades de invertebrados de la nueva desembocadura (localidades 1 y 2) respecto de la del río (localidad 3). of total abundance) and the littoral (97\% of total abundance), and no insects were recorded in the new mouth other than Ceratopogonidae (1\% of total abundance) and Chironomus salinarius (1\% of total abundance) in the multihabitat samples (Fig. 5). Although their abundances were low, certain brackish-water species (e.g., Nereis diversicolor and Orchestia gammarellus) and certain marine bivalve species (e.g., Acanthocardia tuberculata and Mytilus galloprovincialis) colonised and were recorded in the new mouth (Fig. 5).

\section{DISCUSSION}

Based on the physico-chemical data and the aquatic macroinvertebrate communities, two different periods could be distinguished in the present study: before and after the new river mouth was connected to the river and the sea.

\section{Before connection}

During this period, the function of the new river mouth was similar to that of a lagoon. The new mouth was disconnected from the river and the sea and exclusively fed by the superficial aquifer. Because the percentage of species shared with station 3, located approximately $1.8 \mathrm{~km}$ upstream from station 2, was very low, it is possible that the primary route of colonisation by aquatic macroinvertebrates during this period was the surrounding lagoons. The chironomids Ablabesmyia monilis, Polypedilum nubifer and Tanypus punctipennis, the dominant species in the sediment of the new mouth (stations 1 and 2), were not recorded at station 3, whereas they have been recorded at high densities in the adjacent lagoon of Cal Tet (Cañedo-Argüelles \& Rieradevall, 2011) and in several water bodies within the deltaic plain (Cañedo-Argüelles \& Rieradevall, 2009; Sànchez-Millaruelo et al., 2009). The dominance of these species at stations 1 and 2 during this period and their absence from station 3 could have been related to the presence of charophytes in the new river mouth (personal observation) because they have been reported 


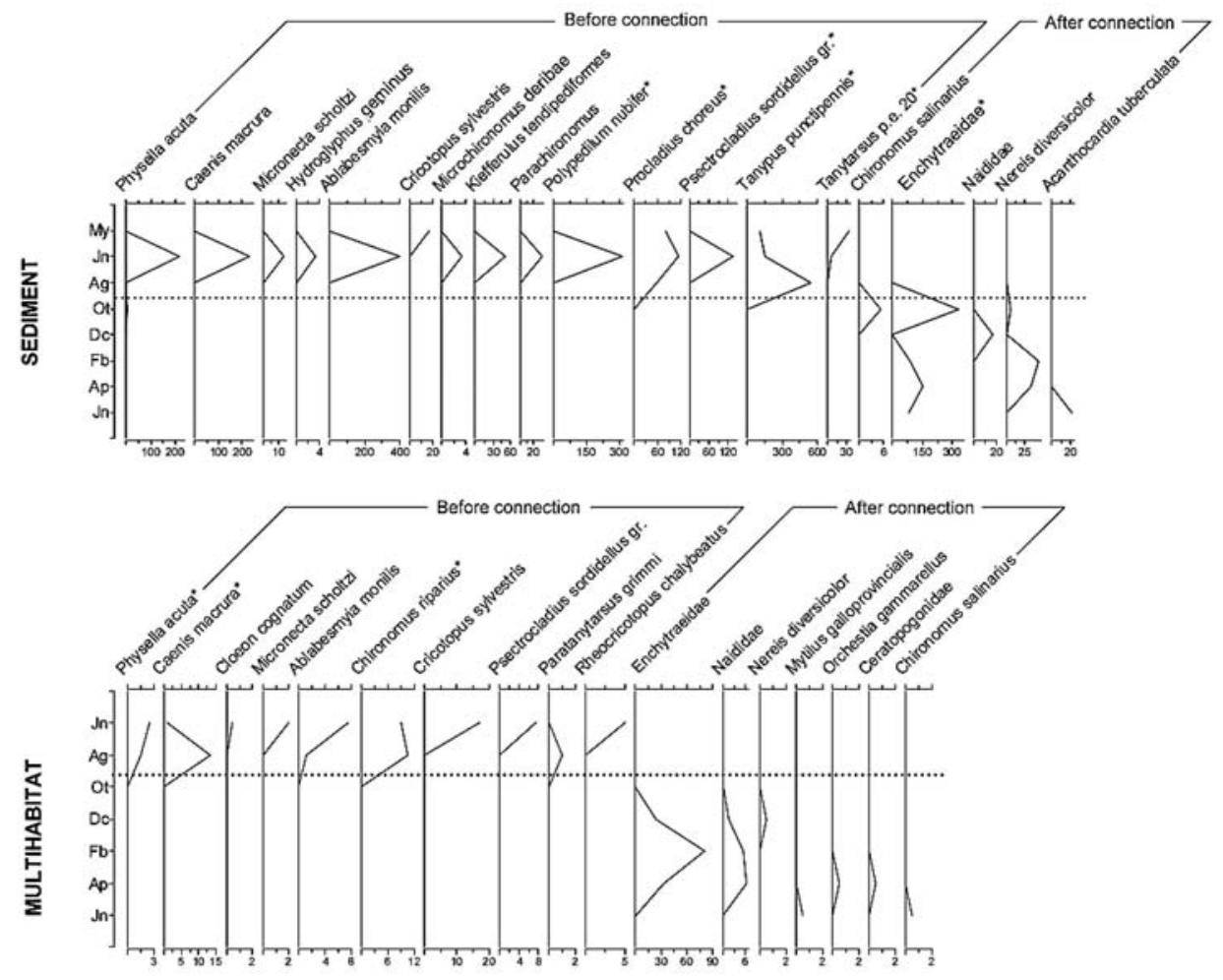

Figure 5. Macroinvertebrate abundances (individuals sample ${ }^{-1}$ ) and densities (individuals $\mathrm{m}^{-2}$ ), registered in the multihabitat and sediment samples respectively, collected in the new mouth (mean values of stations 1 and 2) along the study period (y axis). Taxa are grouped according to the most probable group (and after the connection of the new mouth to the river and to the sea) resulting from the IndVal analysis. The dashed line marks the moment of the opening (September 2004). * = taxa significantly associated to the group according to the IndVal analysis. Abundancias (individuos muestra ${ }^{-1}$ ) y densidades (individuos $\mathrm{m}^{-2}$ ) de macroinvertebrados registradas en las muestras multi-hábitat y de sedimento, respectivamente, recolectadas en la nueva desembocadura (valores promedio para las localidades 1 y 2) durante el período de estudio (eje de las Y). Los taxones están agrupados según su grupo de pertenencia más probable (antes o después de la conexión de la desembocadura con el río y el mar) según los resultados del análisis IndVal. Las líneas discontinuas marcan el momento en el que se produjo la conexión de la nueva desembocadura (Septiembre del 2004). * = taxones asociados de manera significativa al grupo de acuerdo con el análisis IndVal.

to be positively correlated with the presence of Chara (Armitage et al., 1995; Jeppesen et al., 1998; Brodersen et al., 2001; Cañedo-Argüelles \& Rieradevall, 2011). Chironomidae represented most of the macroinvertebrate relative abundance in the new mouth during this period. This dominance was most likely related to the high dispersal abilities of this group (Bilton et al., 2001) and their high growth and reproduction rates (Armitage et al., 1995), which allow them to rapidly colonise new habitats (Barnes, 1983; Christman \& Voshell, 1993; Velasco et al., 1993; Koskenniemi, 1994; Solimini et al., 2003; Cañedo-Argüelles \& Rieradevall, 2011).

\section{After connection}

The sudden increase in conductivity from 4$6 \mathrm{mS} \mathrm{cm}{ }^{-1}$ to $24-30 \mathrm{mS} \mathrm{cm} \mathrm{cm}^{-1}$ caused substantial changes in the macroinvertebrate community of the new mouth after its connection to the river and the sea. A replacement of freshwater taxa by brackish-water and marine taxa is known to occur beyond $5 \%$ salinities $\left(\approx 6.58 \mathrm{mS} \mathrm{cm}^{-1}\right)$ in coastal environments (Remane \& Schlieper, 1971; Barnes, 1989; Jeppesen et al., 2007). The change from one community to the other was not instantaneous. Defaunation occurred after the connection. Three months later, oligochaetes 
of the family Enchytraeidae had completely colonised the new mouth at high levels of abundance. The rapid colonisation by oligochaetes was most likely related to their high growth rates and their asexual reproduction, which allow their populations to increase rapidly (Tachet et al., 2000; Verdonschot, 2006). Oligochaetes and polychaetes (which colonised the new mouth at the same time) are known to be opportunistic taxa and have been shown to colonise new habitats rapidly in defaunation experiments (Zajac \& Whitlatch, 1982; Lu \& Wu, 2000) and after massive macroinvertebrate mortalities during organic enrichment episodes or dystrophic crises (Pearson \& Rosenberg, 1978; Santos \& Simon, 1980; Warwick \& Clarke, 1994; Reizopoulou et al., 1996; Lardicci et al., 1997). The dominance of these opportunistic taxa and the low richness and diversity of taxa recorded might have been linked to the inability of riverine macroinvertebrates to colonise the new mouth due to the restrictions imposed by high conductivities (Williams \& Hamm, 2002; Kefford et al., 2007).

Deltas are riverine-dominated ecosystems (Day et al., 1997) in which sediment and water outflow occur in the river mouth area (Zaldívar et al., 2008). These areas show a longitudinal conductivity and productivity gradient regulated by the mixing of river and seawaters (Levin et al., 2001; Boyes \& Elliott, 2006), which create a transition zone where estuarine $(\approx$ brackishwater) fauna become established (Ysebaert et al., 1993; Rundle et al., 1998; Cognetti \& Maltagliati, 2000; Williams \& Hamm, 2002; Teske \& Wooldridge, 2003). In the case of the Llobregat Delta estuary, previous studies from 1982 (Prat et al., 1983) reported conductivities ranging from 2 to $5 \mathrm{mS} \mathrm{cm} \mathrm{cm}^{-1}$ and eutrophic waters a few hundred metres landwards. This information suggests a strong riverine influence along the estuary, as could be expected in a Mediterranean estuary with low tidal influence. According to the present study, the new mouth showed very different conditions. Estuarine conditions are created by the balanced mixture of freshwater coming from the river and seawater penetrating from the coast. The water fluxes in the new mouth were unbalanced due to the human inter- vention. The river flow has been substantially reduced by numerous dams and water diversions along the river catchment (Lloret, 2004). As a result, very low freshwater discharges enter the new river mouth. At the same time, seawater penetrated the mouth up to the connection point with the river (approximately $3.9 \mathrm{~km}$ upstream). This outcome was a result of the design of the new mouth. As previously mentioned, the new mouth is $250 \mathrm{~m}$ wide and has a mean depth of $2 \mathrm{~m}$ (contrasting with the $0.4 \mathrm{~m}$ of depth in the upper river section). This geometry produced an extensive slope at the connection point between the river and the new mouth and allowed a large-scale penetration of seawater and an accompanying salinisation of the new mouth. Consequently, a drastic change occurred from a diverse freshwater macroinvertebrate community to an impoverished community that included marine species such as Acanthocardia tuberculata and Mytilus galloprovincialis. It can be stated that after its connection with the river and the sea, the new mouth became an arm of the sea. The lower oxygen concentration recorded at station 1 relative to station 2 and the shift from the dominance of the oxidized to the reduced forms of nitrogen represented the development of a confinement gradient, typical of coastal waters with low water renewal (Guelorget \& Perthuisot, 1992). The areas with lower water renewal have a higher oxygen demand due to the accumulation of organic material that must be degraded, and hypoxia is a frequent phenomenon (Tett et al., 2003; Newton \& Mudge, 2005; Mudge et al., 2007; Cañedo-Argüelles et al., in press). Therefore, several management actions need to be considered if an estuarine ecosystem is to be established rather than a marine ecosystem. It is probable that the most desirable option would be to re-establish river flow. This option would mean that more freshwater entered the system, but sediments would also be transported to fill up the new mouth and reduce the penetration of seawater. The management goal should be to use the energy of natural pulses to guarantee the sustainability of the estuarine and the deltaic ecosystem (Day et al., 1997). However, given the location of crucial infrastructure near the margins 
of the river mouth (i.e., the airport and the port), the design and management objectives have been chosen to avoid flooding episodes. To assess how far the Llobregat mouth is from natural conditions, further research during wet years and/or flooding episodes is necessary to understand the dynamics of the new mouth and to analyse the river's ability to break the resistance of the sea and create a strong salinity gradient. It is probable that such a gradient would produce major changes in the macroinvertebrate communities.

\section{ACKNOWLEDGEMENTS}

This project was financed by the Generalitat de Catalunya. We thank the Consorci del Delta del Llobregat and Taller d'Enginyeria Ambiental for providing logistical support. In addition, we thank Roser Farrés for her assistance with field work. Taxonomic advice was provided by Dr. J. Alba-Tercedor for Ephemeroptera and Dr. D. Martín for Polychaeta. Several UB undergraduate biology students also helped in the laboratory.

\section{REFERENCES}

ALONSO, M., CAMBRA, J., GIL, M., GONZÁLEZ, G., JUAME, D., PINO, J., REAL, M., RICO, E., SALÓ, E., VILASECA \& J. 2001. Estudio del impacto sobre los organismos aquáticos de las obras de ampliación del aeropuerto de Barcelona. AENA, Barcelona. 194 pp.

ARMitAGE, P. D., CRANSTON, P. S. \& L. C. V. PINDER. 1995. The Chironomidae: Biology and Ecology of Non-biting Midges. Chapman \& Hall: London. 572 pp.

BARNES, L. E. 1983. The colonization of ball-clay ponds by macroinvertebrates and macrophytes. Freshwater Biology, 13: 561-578.

BARNES, R. 1995. Brackish-Water Fauna of Northwestern Europe. Cambridge University Press: Cambridge. 287 pp.

BARNES, R. S. K. 1989. What, if anything, is a brackish-water fauna? Transactions of the Royal Society of Edinburgh: Earth Sciences, 80: 235-240.

BASSET, A., N. GALUPPO \& L. SABETTA. 2006. Environmental heterogeneity and benthic macroin- vertebrate guilds in italian lagoons. Transitional Waters Bulletin, 1: 48-63.

BATZER, D., R. RADER \& S. WISSINGER. 1999. Invertebrates in Freshwater Wetlands of North America: Ecology and Management. John Wiley and Sons. $1100 \mathrm{pp}$.

BILTON, D. T., J. R. FREELAND \& B. OKAMURA. 2001. Dispersal in Freshwater Invertebrates. Annual Review of Ecology and Systematics, 32: 159181.

BONADA, N., N. PRAT, V. H. RESH \& B. STATZNER. 2006. Developments in aquatic insect biomonitoring: a comparative analysis of recent approaches. Annual Review of Entomology, 51: 495-523.

BOYES, S. \& M. ELLIOTT. 2006. Organic matter and nutrient inputs in the Humber Estuary, England. Marine Pollution Bulletin, 53: 136-143.

BRODERSEN, K. P., B. V. ODGAARD, O. VESTERGAARD \& J. ANDERSON. 2001. Chironomid stratigraphy in the shallow and eutrophic lake Søbygaard, Denmark: chironomid-macrophyte coocurrence. Freshwater Biology, 46: 253-267.

CAÑEDO-ARGÜELLES, M. \& M. RIERADEVALL. 2009. Quantification of environment-driven changes in epiphytic macroinvertebrate communities associated to Phragmites australis. Journal of Limnology, 68: 229-241.

CAÑEDO-ARGÜELLES, M. \& M. RIERADEVALL. 2011. Initial succession of the macroinvertebrate community in a shallow lake: response to changes in the habitat condition. Limnologica, 41: 363370.

CAÑEDO-ARGÜELLES, M., M. RIERADEVALL, R. FARRÉS-CORELL \& A. NEWTON. (In press). Annual characterisation of four Mediterranean coastal lagoons subjected to intense human activity. Estuarine, Coastal and Shelf Science.

COGNETTI, G. \& F. MALTAGLIATI. 2000. Biodiversity and adaptive mechanisms in brackish water fauna. Marine Pollution Bulletin, 40: 7-14.

CROSSLAND, C., H. KREMER, H. LINDEBOOM, J. CROSSLAND \& M. LE TISSIER. 2005. Coastal Fluxes in the Anthropocene. SpringerVerlag: New York. 232 pp.

CHRISTMAN, V. D. \& J. R. VOSHELL. 1993. Changes in the benthic macroinvertebrate community in two years of colonization of new experimental ponds. Internationale Revue der Gesamtem Hydrobiologie, 78: 481-491. 
DAY, J. W., J. F. MARTIN, L. CARDOCH \& P. H. TEMPLET. 1997. System functioning as a basis for sustainable management of deltaic ecosystems. Coastal Management, 25: 115-153.

DUFRÊNE, M. \& P. LEGENDRE. 1997. Species Assemblages and Indicator Species: The Need for a Flexible Asymmetrical Approach. Ecological Monographs, 67: 345-366.

EUROPEAN COMMISSION. 2000. Directive 2000/ 60/EC of the European Parliament and of the Council of 23 October 2000 establishing a framework for Community action in the field of water policy. Official Journal of the European Communities, 43: 1-72.

GOLDEN SOFTWARE, I.t.S., Golden, Colorado 80401-1866, U.S.A., SURFER 8.0.

GREENBERG, A. E., L. S. CLESCERI \& A. D. EATON. 1999. Standard methods for the examination of water and wastewater, 20 ed. American Public Health Association. 1325 pp.

GUELORGET, O. \& J. P. PERTHUISOT. 1992. Paralic ecosystems. Biological organization and functioning. Vie et Milieu, 42: 215-251.

JACKSON, J. K. \& L. FÜREDER. 2006. Long-term studies of freshwater macroinvertebrates: a review of the frequency, duration and ecological significance. Freshwater Biology, 51: 591-603.

JEPPESEN, E., M. SØNDERGAARD, M. SØNDERGAARD \& K. CHRISTOFFERSEN. 1998. The structuring role of submerged macrophytes in lakes. Springer: New York. 471 pp.

JEPPESEN, E., M. SØNDERGARD, A. R. PEDERSEN, K. JÜRGENS, A. STRZELCZAK, T. L. LAURIDSEN \& L. S. JOHANSSON. 2007. Salinity induced regime shift in shallow brackish lagoons. Ecosystems, 10: 47-57.

KEFFORD, B., D. NUGEGODA, L. ZALIZNIAK, E. FIELDS \& K. HASSELL. 2007. The salinity tolerance of freshwater macroinvertebrate eggs and hatchlings in comparison to their older life-stages: a diversity of responses. Aquatic Ecology, 41:335348.

KOSKENNIEMI, E. 1994. Colonization, succession and environmental conditions of the macrozoobenthos in a regulated, polyhumic reservoir, western Finland. Internationale Revue der Gesamtem Hydrobiologie, 79: 521-555.

LARDICCI, C., F. ROSSI \& A. CASTELLI. 1997. Analysis of macrozoobenthic community structure after severe dystrophic crises in a Mediterranean coastal lagoon. Marine Pollution Bulletin, 34: 536-547.

LEVIN, L. A., D. F. BOESCH, A. COVICH, C. DAHM, C. ERSÉUS, K. C. EWEL, R. T. KNEIB, A. MOLDENKE, M. A. PALMER, P. SNELGROVE, D. STRAYER \& J. M. WESLAWSKI. 2001. The function of marine critical transition zones and the importance of sediment biodiversity. Ecosystems, 4: 430-451.

LU, L., \& R. S. S. WU. 2000. An experimental study on recolonization and succession of marine macrobenthos in defaunated sediment. Marine Biology, 136: 291-302.

LLORET, R. 2004. La qualitat de l'aigua del riu Llobregat. Un factor limitant del passat, un element clau per al futur. In: El Baix Llobregat: història $i$ actualitat ambiental d'un riu. N. Prat Fornells, E. Tello Aragay (Eds.): 94-141. Centre d'Estudis Comarcals del Baix Llobregat.

MCCUNE, B. \& J. MEFFORD. 1999. PCORD: Multivariate Analysis of Ecological Data, 4.20 ed. MjM software, Oregon.

MERRITT, R. W. \& K. W. CUMMINS. 1996. An introduction to the aquatic insects of North America. Kendall/Hunt Publishing: Iowa. 862 pp.

MILLET, X. \& N. PRAT. 1984. Las comunidades de macroinvertebrados a lo largo del rio Llobregat. Limnetica, 1: 222-223.

MUDGE, S. M., J. D. ICELY \& A. NEWTON. 2007. Oxygen depletion in relation to water residence times. Journal of Environmental Monitoring, 9: 1194-1198.

NEWTON, A. \& S. M. MUDGE. 2005. Lagoon-sea exchanges, nutrient dynamics and water quality management of the Ria Formosa (Portugal). Estuarine, Coastal and Shelf Science, 62: 405-414.

PEARSON, T. H. \& R. ROSENBERG. 1978. Macrobenthic succession in relation to organic enrichment and pollution of the marine environment. Oceanography and Marine Biology Annual Review, 16: 229-311.

PRAT, N., M. A. PUIG \& G. GONZÁLEZ. 1983. Predicció i control de la qualitat de les aigües dels rius Besós i Lobregat. II. El poblament faunístic $i$ la seva relació qualitat-aigües. Diputació de Barcelona. Col. Monografies, Barcelona. 164 pp.

PRAT, N. \& M. RIERADEVALL. 2006. 25-years of biomonitoring in two mediterranean streams (Llobregat and Besòs basins, NE Spain). Limnetica, 25: 541-550. 
REIZOPOULOU, S., M. THESSALOU-LEGAKI \& A. NICOLAIDOU. 1996. Assessment of disturbance in Mediterranean lagoons: an evaluation of methods. Marine Biology, 125: 189-197.

REMANE, A. \& C. SCHLIEPER. 1971. Biology of brackish water. Wiley Interscience: New York. 372 pp.

RUNDLE, S. D., M. J. ATTRILL \& A. ARSHAD. 1998. Seasonality in macroinvertebrate community composition across a neglected ecological boundary, the freshwater-estuarine transition zone. Aquatic Ecology, 32: 211-216.

SÁNCHEZ-JUNY, M. \& J. DOLZ RIPOLLÉS. 2004. El riu, un camí dáigua. In: El Baix Llobregat: història i actualitat ambiental d'un riu. N. Prat Fornells, E. Tello Aragay (Eds.): 32-47. Centre d'Estudis Comarcals del Baix Llobregat.

SÀNCHEZ-MILLARUELO, N., M. CAÑEDO-ARGÜELLES \& M. RIERADEVALL. 2009. Avaluació de la biodiversitat i l'estat ecològic de les llacunes i canals del Delta del Llobregat mitjançant l'ús de les exúvies de quironòmids com a bioindicadors, 5enes Jornades d'Estudi del Patrimoni del Baix Llobregat: Patrimoni en un entorn metropolità. Consorci del Prat, El Prat, Barcelona: 83-88.

SANTOS, S. L. \& J. L. SIMON. 1980. Response of soft-bottom benthos to annual catastrophic disturbance in a South Florida Estuary. Marine Ecology Progress Series, 3: 347-355.

SOLIMINI, A. G., A. RUGGIERO, V. BERNARDINI \& G. CARCHINI. 2003. Temporal pattern of macroinvertebrate diversity and production in a new man made shallow lake. Hydrobiologia, 506-509: 373-379.

TACHET, H., P. RICHOUX, M. OURNAUD \& P. USSEGLIO-POLATERA. 2000. Invertébrés d'eau douce: Systématique, biologie, écologie. CNRS Editions: Paris. 587 pp.

TER BRAAK, C. \& P. ŠMILAUER. 2002. Canoco for Windows, version 4.5., 4.5. ed, Wageningen, The Netherlands.

TESKE, P. R. \& T. H. WOOLDRIDGE. 2003. What limits the distribution of subtidal macrobenthos in permanently open and temporarily open/closed
South African estuaries? Salinity vs. sediment particle size. Estuarine, Coastal and Shelf Science, 57: 225-238.

TETT, P., L. GILPIN, H. SVENDSEN, C. P. ERLANDSSON, U. LARSSON, S. KRATZER, E. FOUILLAND, C. JANZEN, J. Y. LEE, C. GRENZ, A. NEWTON, J. G. FERREIRA, T. FERNANDES \& S. SCORY. 2003. Eutrophication and some European waters of restricted exchange. Continental Shelf Research, 23: 1635-1671.

VAN DEN BRINK, P. \& C. TER BRAAK. 1999. Principal response curves: analysis of timedependent multivariate responses of a biological community to stress. Environmental Toxicology and Chemistry, 18: 138-148.

VELASCO, J., A. MILLÁN, \& L. RAMÍREZ-DÍAZ. 1993. Colonización y sucesión de nuevos medios acuáticos II. Variación temporal de la composición y estructura de las comunidades de insectos. Limnetica, 9: 87-98.

VERDONSCHOT, P. F. M. 2006. Beyond masses and blooms: the indicative value of oligochaetes. $\mathrm{Hy}$ drobiologia, 564: 127-142.

WARWICK, R. M. \& K. R. CLARKE. 1994. Relearning the ABC: taxonomic changes and abundance/ biomass relationships in disturbed benthic communities. Marine Biology, 118: 739-744.

WILLIAMS, D. D. \& T. HAMM. 2002. Insect community organisation in estuaries: the role of the physical environment. Ecography, 25: 372-384.

YSEBAERT, T., P. MEIRE, D. MAES \& J. BUIJS. 1993. The benthic macrofauna along the estuarine gradient of the Schelde Estuary. Netherlands Journal of Aquatic Ecology, 27: 327-341.

ZAJAC, R. N. \& R. B. WHITLATCH. 1982. Responses of estuarine fauna to disturbance. I. Spatial and temporal variation of initial recolonization. Marine Ecology Progress Series, 10: 1-14.

ZALDÍVAR, J. M., A. C. CARDOSO, P. VIAROLI, A. NEWTON, R. DE WIT, C. IBAÑEZ, S. REIZOPOULOU, F. SOMMA, A. RAZINKOVAS, A. BASSET, M. HOLMER \& N. MURRAY. 2008. Eutrophication in transitional waters: an overview. Transitional Waters Monographs, 1: 11-78. 